Original Research Paper

\title{
Sense Distortions in the Mass Media: Their Social Consequences
}

\author{
Galina Sergeevna Melnik, Boris Yakovlevich Misonzhnikov, \\ Anastasiya Nikolayevna Grishanina and Alla Nikolayevna Teplyashina \\ School of Journalism and Mass Communications, St. Petersburg State University, Russia
}

\author{
Article history \\ Received: 04-03-2016 \\ Revised: 04-05-2016 \\ Accepted: 11-06-2016 \\ Corresponding Author: \\ Alla Nikolayevna Teplyashina \\ School of Journalism and Mass \\ Communications, St. \\ Petersburg State University, \\ Russia \\ Email: teplyashina.a@bk.ru
}

\begin{abstract}
The paper presents the results of the monitoring of St. Petersburg newspapers held in January-May 2015. The monitoring included qualitative and quantitative study of the content and evaluation of all the materials published in St. Petersburg newspapers. Special attention was given to such sections as Society, Politics, Law, Economy. The purpose of monitoring regional press was to detect errors or misstatements in the media sources, including online media. Semantic distortion was found in 204 publications. Violations of journalism ethics give rise to the problem of information distortion and, as a consequence, useless, poor-quality information deforms the reality communicated to the audience. Systematizing the violations of ethical principles of journalism give a clear picture of the present-day Russian mass media and open up the ways to improve self-regulatory mechanisms. The study reported here is unique as it is the first research focusing on ethical violations in Russian mass media. The results of the study are used as case studies to analyze ethical conflicts, as materials to promote professional standards for journalists investigating corruption schemes, etc. The monitoring data is included in the study that will be discussed at the permanent international seminar on the ethics of journalism Ethics of Mass Communication: Research in Russia and abroad. The first seminar was held on October 3-4, 2013 at the High School of Journalism and Mass Communications, St. Petersburg State University, with the support of the German House of Research and Innovation in Moscow and the Consulate General of Germany in St. Petersburg.
\end{abstract}

Keywords: Journalism Ethics, Violations of Ethical Principles, Media Research, Self-Regulatory Mechanisms, Poor Quality Information

\section{Introduction}

Scientists in the West and in Russia addressed the problem of information distortion as a result of violations of ethical standards by journalists. To truly understand what ethics is requires philosophical generalization of ontology of modern society, calls for an awareness that we live on the threshold of noosphere. According to Zarefsky, "But if we do not engage our values in argument, we cannot make designs democratically. We must either rely on some kind of force-the coercion of military power, the weight of authority, or the threat of reprisal-or we must settle for pure relativism, according to which no one value is preferable to any other... I may value freedom and you may value tyranny and there is no way to choose between us. The history of the last century is littered with object lessons suggesting that we must not settle for these alternatives" (Zarefsky, 2014: 5). The problem often lies in the criterion of an argument, in its blamelessness. This idea is applicable in building up the argumentation in journalistic discourse.

Christians et al. (2009), as print media researchers, underline that the European model of journalism has always focused on common values-freedom of press and opinion, freedom of communication, which secured journalism a crucial role in European society. Dunas points out that the technological progress, providing media professionals with enormous opportunities, affects professional standards of editorial offices which continually violate ethical principles in response to fickle demands of their audiences (Dunas, 2014: 128-146). According to Christians, Glasser, McQuail, 
Nordenstreng and White, the institution of journalism has become a part and parcel of European concepts of democracy, which state that to follow all the required principles-service to the society, social responsibility, accountability to the authority, criticism of the elite and the establishment-journalism should be guaranteed professional independence and editorial freedom (Christians et al., 2009). Trappel and Meier (2011) are also concerned about the preservation of the standards of quality journalism. According to Davies, ethical principles are violated due to tough deadlines imposed by increased information flows, reduction of staff and investment. The nature of factors affecting professional editorial standards is complex and inconsistent. It is dependent on the sources of information and for many journalists a source of information is an external factor that has to do with a professional news environment or personal connections. The results of the study conducted by a team from Cardiff University show that reporters gather no more than $20 \%$ of the total news stories beyond editorial offices-the remaining $80 \%$ are borrowed from external sources. Besides that, the study found that even when a publication was initiated by a journalist, they did not have time to refer to several sources (Davies, 2009).

In modern scholarly works on Russian media, much is said about ethical evaluation. "On the one hand, ethical and professional standards are a way to monitor the activity; on the other hand, they are the criteria for evaluating its effectiveness" (Duskaeva, 2009: 8). Some researchers provide accounts of journalists who cross the line separating the possible and the permissible from what is considered poor practice (Maidanova and Chepkina, 2009: 135-166).

The proceedings of the seminar held as part of the professional development program Ethics of Mass Communications-Ethics of Mass Communications: Practice and Research in Russia and Germany is a collection of papers and other materials presented at the seminar. The event was organized by the High School of Journalism and Mass Communications of St. Petersburg State University with financial and organizational support from the German House of Research and Innovation in Moscow (DWIH) and the Consulate General of Germany in St. Petersburg (Korkonosenko, 2013). Among others, it gives examples of how violation of ethics occurs through photographs and pictures. Incorrect use of images, their manipulation and misinterpretation can change their meaning or even lead to distortion of facts. This casts doubt on the natural properties of photographs-their role in capturing and reflecting the reality (Fedorova, 2013:82-85). Researchers give examples of mass media practices which promote aggressive, immoral, traumatic or malicious information. These examples are contained in a monograph on the ethics of speech of Russian journalists (Herz and Molnar, 2010: 79-103; Glazkova, 2013:187-193).
Ovcharenko provides an overview of content analysis of several Canadian media. She studied the contributions made by Canadian media experts to Canadian Journal of Communication in 2010-2011 (Ovcharenko, 2011). These studies explain why Canada loses ground in all types of media. The problem is primarily in the quality of information.

Smirnova was the first to define the concept of a professional ethical norm, based on distinctive, functional and structural analysis. It was shown that the norm is not only an element but a fundamental unit of professional ethics in journalism (Smirnova, 2014). Tulupov sets to explain the concept of a professional standard. He identifies several professional standards that journalists have to follow: The separation of fact and comment; careful interpretation (especially when it comes to conflict situations); ethical positions; balanced point of view; review of sufficient number of documents, no anonymous sources; efficiency (combined with diligence); truthfulness (an ability to admit mistakes); tolerance; independence of editorial from advertising (the latter refers to the edition as a whole), etc. (Tulupov, 2012).

Having summarized the results of media researchers, all information received by the mass media audience can be differentiated as a high-quality, useless, poor quality one, which requires new research.

High-quality information is that which properly reflects the actual reality and is necessary for the interpretation of the event, process, etc.

Poor quality information is that which is necessary to interpret the event, process, situation, but it reflects the reality improperly.

Useless information is that which is not necessarily required to interpret the event, process, to make a specific decision, etc.

Useless information in turn is subdivided into information that is not related to the situation and redundant information.

Redundant information is that which exceeds the required one for an objective interpretation of the event, process, etc. In contrast to the information, unrelated to the event, situation, etc. the redundant information is relevant to the interpretation, but it is not necessary at the given moment. Redundant information can be exemplified by unnecessary details, repeated information. A negative result from the use of the redundant information is a waste of time and a distraction of attention from the main point. Sometimes this is used in order to conceal the main things.

The types of poor quality information include disinformation. Disinformation is commonly understood as fictional or inexact, incomplete information, which is a consequence of the violations of journalism ethics.

We should note that high-quality information is of the axiological nature, so the systematization of ethical 
violations, dominant in the media space and the identification of the links existing between them can give a detailed idea about the features of the Russian mass media at the present stage and discover ways to improve the self-regulatory mechanisms.

It is becoming increasingly difficult to separate journalism as an institution that provides the public with objective and reliable information about the reality from the other streams of mass communications (advertising, PR, entertainment industry and political propaganda). The international journalistic community is trying to resist the convergent processes, creating organizations aimed at studying the fundamental values of modern journalism. Thus, in 1997 the Committee of Concerned Journalists was created in America (CCJ, 2009), where opinion surveys have been carried out among journalists and audiences for several years, the main purpose of these surveys being to identify the fundamental values and motivations that govern the modern journalistic community, as well as the degree of their adequacy with the expectations of the audience. The results of this long-lasting work have been summarized in the book "The Elements of Journalism: What Newspeople Should Know and the Public Should Expect" (Kovach and Rosensteil, 2001). International and European Federation of Journalists have initiated the Ethical Journalism Initiative (White, 2008) and Stand up for Journalism (IFJ, 2007) movements whose purpose is to return the core values to journalism, among which the quality of the published information should be highlighted.

The area of interest of current Russian studies in the field of journalism was to identify semantic distortions in the mass media texts determined by the objective and subjective factors. The probability of such consequences can be detected with the help of technological and audience-oriented factors of presenting information. Methodological developments in this field of research contained in the works by White (2008); Davies (2009); Christians et al. (2009); Blokhin and Korkonosenko (2011); Trappel et al. (2011); Herz and Molnar (2012); Voltmer (2012); Weaver and Willnat (2012); Franklin (2013); Dunas (2014) and others are widely known. The following authors underline the necessity of examining the reliability (distortion) of information to determine as precisely as possible the possibilities and limitations of modern editions: Maidanova and Chepkina (2009; Tulupov, 2012; Ovcharenko, 2011; Zarefsky, 2014; Glazkova, 2013; Fedorova, 2013; Shishkin and Taranova, 2013; Smirnova, 2014).

Melnik et al. (2015) emphasize that the information on the political resources becomes more and more extremist and apprears in large quantities. In pursuit of the autonomy and independence of political texts the authors seek to overcome the established boundaries unfailing society and violating the professional ethics.
The article by Baichik et al. (2015) proposes a definition of noopolitics, as an information strategy, with the following features to identify the real objectives of the parties in opposition to the information, as well as unethical techniques used in it. The concept of "political defamation" is introduced in the scientific revolution; it allows characterizing the course of action of the media.

Bekurov et al. (2015) in their article focus on the role of social media in the sociopolitical processes; in particular, the use of such resources in mobilization technologies and their impact on the protest campaigns are reviewed. Social media change the shape and channels of delivering political information to the citizens, they have their own alternative mechanisms of forming information on the agenda and, as a platform of civil journalism, by definition take an active part in the mediatization of sociopolitical processes both at the national level and in solving global problems. In the meantime, such participation has both positive and negative connotations.

Online School of Journalism and Mass Communication (USA, University of Wisconsin) published scientific works about Digital Media Ethics (Ward, n.d.). Digital news media includes online journalism, blogging, digital photojournalism, citizen journalism and social media. It includes questions about the ways how professional journalism should use this new media to research and publish stories, as well as how to use text or images provided by citizens. Some of the material is devoted to the Global Media Ethics, which addresses development of a comprehensive set of principles and standards for the practice of journalism in the age of global news media.

The school web-site publishes information about conferences on Professional Ethics, for example, "2016: Race, ethnicity and journalism ethics" (2016).

New Journal of Philosophical, Theological and Applied Ethics (JPTAE, 2016) organized debates concerning ethical questions related to the criminal justice systems, civil law, public law and ethics and religious legal traditions and ethics. A book edited by Gumpert and Drucker (2016) "Regulating Social Media: Legal and Ethical Considerations" was published in a Special Issue "Ethics and Law". The authors point out in this article that "Scholarly researchers of social media have not yet focused on the rights of expression and ethical obligations of the new media environment. Convergence, participatory culture, multimedia technologies and social media platforms are creating new communicative opportunities that fundamentally influence citizenship and journalism. Social media presents a staggering breadth of legal and ethical matters to consider. The limits and laws of free expression in this new media landscape are beginning to emerge both domestically and internationally, causing us to ask the 
following questions: How do we conceive of privacy? Should the law protect citizen journalists?, etc."

\section{Methods and Techniques}

The paper discusses the results obtained during the media monitoring, in particular those which refer to the violations of ethical principles of journalism and selfregulatory mechanisms. It is important that not only professionalism, but also professional ethics should become top priority for modern journalism. Editorial practices show that the introduction of strong ethical principles leads to the relaxation of rules, which then look very different from those declared. To reduce the gap between the requirements of the code of ethics and minimal restrictions requires constant monitoring of violations and benchmarking the scope of violations against international principles of conduct for journalists. The research team followed the basic monitoring principles: The principle of openness-editorial boards were aware of the monitoring methodology and its results; the principle of independence-monitoring results are based on expert evaluation, self-sufficient and independent of specific media type; the principle of objectivitymonitoring results reflect the current situation in journalism and are not slanted by individual opinions or biases of the research team. Experts involved in the monitoring possess the required level of knowledge and skills; the principle of legality-the monitoring was conducted in compliance with mass media regulations.

The purpose of the regional press (St. Petersburg, Russia) monitoring is detection of errors or distortion of information in the press sources and online media to inform the public about the unreliable, poor-quality information, the dissemination of which could result in adverse social consequences.

Mass media monitoring was accompanied by application of comparative and structural analysis of the sources, the comparative method (comparative historical analysis of texts with elements of media branding study).

The procedure of the mass media monitoring and comparative analysis revealed that the distortion of information in the media often has the same sociopsychological consequences as the informational negative. The social policy of the state (community or individual institutions, which include the mass media) leads to certain consequences in terms of socio-psychological attitude: Negative, neutral and positive. The mass media should pay attention to the socio-psychological aspects of the published information. The attention or neglect to these issues is determined by the competence of journalists, editors and also by newsmakers, officials and legislators involved in these issues.

Monitoring also showed that the mass media attitude to new technologies, the ability to use information resources effects the distortion formation.
To identify ethical violations in the media is to determine the degree of deviation from the high professional standards. These issues are covered by a special branch of science called deontology of journalism. Scholarly works on the ethics of journalism make references to a system of knowledge about the professional duty of journalists with ethical and legal principles at its foundation. The study of ethical and legal standards and self-regulation mechanisms reveals a set of professional values. It should be noted, that when it comes to rights and duties, a journalist is obliged to follow the categorical imperative. If professional behavior of journalists is driven by ethics, it will enhance social responsibility of media professionals and the formation of the civil society in general.

Today the "tablet way" of information presentation dominates, which is mastered by media editorial offices as the process of creating an information product. Communication technologies fight for the reader's attention; the system of unified communications brings together all disparate systems into a single communications platform. Similar to the tablet, the information delivering system can not only process the messages delivered by news agencies and reporters, but choose the way and the time of sending information. Mass media work on the principle of a single communication platform, reducing the news processing period and at the same time directing the reader into those communication streams that benefit the media environment.

With the development of technologies, the production and delivery of news content is changing; interactivity, ultimately, changes the media content. Manufacturability often "dictates" the rules of information selection and writing texts, which becomes the reason for the distorted presentation of information.

Using the Internet as a new information and communication environment for the promotion of their off-line 'parent' brands and also as an additional content provider, newspaper website creators sometimes depart from the typological structure of their issue content and publication frequency. We talk about the use of media platforms-the website where the user can get an access to information and media products with a high degree of interactivity or the possibility to create it on his/her own (Chekasina, 2013). The information is presented via new media: Websites, iPad-versions of magazines and newspapers, their mobile versions (for smartphones), applications, 3G-TV, mp3-players, infoscreens/mediascreens.

The monitoring procedure included a comparative analysis of the headlines of media works. The researchers note that the distortion occurs most often at the level of the correlation between the headline (headline complex) and the text. In the headline the author focuses on the manipulative methods of impact, 
attracts attention, "makes one to read". It has always been the case. Today, the headline attracts attention by that it deliberately highlights not the most important facts, at the same time distorting the meaning of the following text. Thus, the provocative headline "Cozzers' requests" (the Metro newspaper, January 20, 2015) distorts the content at the initial stage of perception. The subtitle says that after the annexation of the Crimea Putin was preparing for a nuclear war. The headline text does not correspond to the text of the article itself, which, with reference to the documentary "Crimea. The way back home", said about the willingness of Moscow to place the nuclear forces on alert, but only in case of an armed confrontation on the part of Western countries. Many titles misinform the reader ("Ukraine leaving Russia", "The Russians to be flipped with money for new housing development" in the Metro newspaper).

The Internet for the user (the reader) is not only a source of information, but also a new type of mass media, as well as a tool for creating new images. Users are free to join the multitude of other information consumers. As for the information owners and distributors, this factor predetermines the need to make special efforts to attract the audience: To study their needs, to take care of positioning (present themselves on the market) and advertising of specific issues, to know the psychological constitution of the network information perception.

The method of observation used in the work showed that the information needs continue to play a vital role in human life, as distortions occur also at the stage of the stating facts in the information. This technique extensively uses the cross-citation.

According to the quarterly ratings of the 2010-2011 the top ten most cited mass media included Fontanka.ru and GAZETA.SPb. The news agency Rosbalt, the Internet resource and news agency BaltInfo were highly cited as well (Blokhin and Korkonosenko, 2011:66).

The analysis of the practice of Fontanka.ru, the most cited online media of Petersburg, revealed that the journalists of this daily mass media do a big job structuring materials display. The home page of Fontanka.ru presents the materials of not only this edition. Great attention is paid by the employees to promote the so-called affiliate websites, which belong to the same media group. Fontanka.ru with its daily website traffic over 125 thousand people is a 'locomotive' for such websites as 47 news.ru, doctorpiter.ru, spbvoditel.ru, kvadrat.ru, fontanka.fi.

The list of editions subjected to the analysis included the newspapers: Metro (20), Moskovsky Komsomolets (18), Komsomolskaya Pravda (10), Argumenty i Facty (14), Novaya Gazeta (19), Vedomosti.ru (7), Izvestia (9), Gazeta.ru (7) and the online media: Lenta.ru (54), News.ru (22), Zaks.ru (7) and Fontanka.ru (16). In parentheses the number of publications in these newspapers is specified.

In general the monitoring revealed the following types of distortions:

- Disinformation, fabrication of facts, manifestation of selective attention to the facts; presentation thereof from a favorable perspective for the manipulator

- Information distortion by means of incorrect (inaccurate) citation for the purpose of the readers' misrepresentation

- $\quad$ Editing, adding different meanings by a journalist, speculations (discrepancy with the reality)

- Accompanying the material with a headline inconsistent with the content; see summary tables"

Social consequences of the publications containing essential and nonessential information distortions require a special study. However, the style and tone of the materials, as well as their straightforward orientation often produce negative social attitudes, promote the segregation of social groups and create tension and conflictogenic zones in the society

One and the same information can be presented in different ways, with rather differing emotional effects and psychological consequences. Online mass media have a tremendous opportunity to manipulate the minds of the audience. Numerical information, quotations from the speeches of politicians and many other things are accompanied by various comments and nonverbal imagery forms (images). Some answers or remarks are selected for publication from the list and other fragments are omitted. Such statements, in fact, are the journalist's or editors' choice.

The monitoring revealed another important factor of distortion a large number of repetitions. This wellknown method is becoming a new form of the mass media influence on the audience. It is rather convincingly proved in the propaganda and advertising psychology that repetitions are characterized by a strong suggestive effect. Arguments are not needed to achieve the goal, it is better not to touch the rational plan, to 'burden' with evidence, justifications and so on. On the contrary, the simpler the judgment is, the easier it is embedded in the subconscious.

The analysis of publications shows that the thesis of "the facts speak for themselves" gives rise to doubts nowadays. Any phenomenon can exist regardless of the subject, but the fact does not exist by itself-it is always only in the description, in the presentation. The events are told about biased, subjectively, with certain preferences and interests.

Thus, the following indicators served as the criteria for evaluating materials: Disinformation, the selectivity of the facts, incorrect citations and misleading headlines. 
Content analysis was used for data processing. The parameters were processed using Microsoft Excel 2007.

\section{Results}

Poor-quality information parameters were classified in the course of study. The sources of typical errors and faults committed by journalists while preparing materials were revealed.

The editorial team is occupied with creating its own news. The most common ways of transmitting information by the correspondent to the Editorial office include 'dictating' on-the-spot commentary and sending the data via e-mail. When there is no possibility to use a computer, the interaction between the editor and correspondent, who is at the event, occurs with the help of a mobile phone not only by calls but also by sending SMS messages. Thus, for example, this method is indispensable for journalists in the courtroom and moreover sometimes five words may be enough, for example: So and so has not admitted his guilt. After receiving the SMS all that is left for the editor to do is to gather information about the case and include all the data in the newspaper item. 'Evidential' losses may occur in this chain when combining information.
Materials for the mass media are also appearing from press releases sent to the editorial office or published on the websites of agencies and companies. Inaccuracies may be contained in the source documents.

Errors arise due to the lack of complete information about the event and information source protection. Journalists resort in this case to the speculations, presenting their own versions without relying on facts.

Biased nature of information or disinformation arise as a consequence of the editorial policy and the commitment of journalists and media founders to certain political views. In this context it is natural that the St. Petersburg network media demonstrate various ways to show evaluativity (and often a negative evaluation of the events and people is given).

The reason for errors may be a low level of expert evaluation (involvement of dubious experts in commenting).

It is required to take into account the trolling factor (troll is a communicator-provocateur who uses (often unconsciously) a set of technologies: Violation of netiquette and rules, media attack, inciting; they are used in the 'information war' of the periodicals to enhance the negative context.

Table 1. (January 1-May 31, 2015)

\begin{tabular}{|c|c|c|c|c|c|}
\hline No. & Distortion Techniques & lenta.ru (54) & news.ru (22) & zaks.ru (7) & fontanka.ru (16) \\
\hline 1. & $\begin{array}{l}\text { Disinformation, fabrication of facts. } \\
\text { Manifestation of selective attention } \\
\text { to the facts from a favorable } \\
\text { perspective for the manipulator }\end{array}$ & $\begin{array}{l}11-\text { politics } \\
\text { (3 retractions) }\end{array}$ & $\begin{array}{l}\text { 2-law } \\
\text { 2-politics } \\
\text { (1retraction) } \\
\text { 1-economics }\end{array}$ & $\begin{array}{l}\text { 1-politics } \\
\text { 1-economics } \\
\text { (retraction) }\end{array}$ & $\begin{array}{l}\text { 3-politics } \\
\text { (1 retraction) } \\
\text { 1-law }\end{array}$ \\
\hline 2. & $\begin{array}{l}\text { Distortion by means of incorrect } \\
\text { citation, misrepresentation }\end{array}$ & $\begin{array}{l}\text { 10-politics } \\
\text { (1 retraction) } \\
1 \text {-economics }\end{array}$ & $\begin{array}{l}\text { 1-economics } \\
\text { 4-politics }\end{array}$ & $\begin{array}{l}\text { 1-politics } \\
\text { 1-law (retraction) }\end{array}$ & \\
\hline 3. & $\begin{array}{l}\text { Editing, adding different meanings, } \\
\text { speculations (discrepancy with the } \\
\text { reality) }\end{array}$ & $\begin{array}{l}\text { 20-politics } \\
\text { (3 retraction) } \\
\text { 1-economics (retraction) }\end{array}$ & $\begin{array}{l}\text { 5-politics } \\
\text { 1-law }\end{array}$ & $\begin{array}{l}\text { 1-politics } \\
\text { 1-law (retraction) }\end{array}$ & $\begin{array}{l}\text { 7-politics } \\
\text { 2-law }\end{array}$ \\
\hline 4. & $\begin{array}{l}\text { Accompanying the material with a } \\
\text { headline inconsistent with the } \\
\text { content. }\end{array}$ & $\begin{array}{l}1 \text {-economics } \\
10 \text {-politics } \\
(3 \text { retractions }) \\
\end{array}$ & $\begin{array}{l}\text { 1-law } \\
\text { 2-economics } \\
\text { 5-politics }\end{array}$ & 1-politics & 3-politics \\
\hline
\end{tabular}

Table 2. (January 1-May 31, 2015)

\begin{tabular}{|c|c|c|c|c|}
\hline No. & Distortion Techniques & $\begin{array}{l}\text { Argumenty i Fakty } \\
\text { (Arguments and Facts) (14) }\end{array}$ & Komsomolskaya Pravda (10) & Novaya Gazeta (19) \\
\hline 1. & $\begin{array}{l}\text { Disinformation, fabrication of facts. } \\
\text { Manifestation of selective attention } \\
\text { to fact from a favorable perspective } \\
\text { for the manipulator }\end{array}$ & $\begin{array}{l}\text { 1-politics } \\
\text { 1-economics (retraction) }\end{array}$ & $\begin{array}{l}\text { 2-politics } \\
(1 \text { retraction })\end{array}$ & $\begin{array}{l}\text { 1-economics } \\
\text { (retraction) } \\
\text { 3-politics }\end{array}$ \\
\hline 2. & $\begin{array}{l}\text { Distortion by means of incorrect } \\
\text { citation, misrepresentation }\end{array}$ & $\begin{array}{l}\text { 2-politics } \\
\text { (1 retraction) } \\
1 \text {-economics }\end{array}$ & 2-politics & $\begin{array}{l}\text { 1-economics } \\
1 \text {-politics }\end{array}$ \\
\hline 3. & $\begin{array}{l}\text { Editing, adding various } \\
\text { Speculations }\end{array}$ & $\begin{array}{l}3 \text {-politics } \\
\text { (1 retraction) } \\
\text { 2-economics } \\
\text { (1 retraction) }\end{array}$ & 3-politics & $\begin{array}{l}\text { 1-economics } \\
3 \text {-politics } \\
\text { ( } 1 \text { retraction) }\end{array}$ \\
\hline 4. & $\begin{array}{l}\text { Accompanying the material with } \\
\text { a headline inconsistent with the } \\
\text { content. }\end{array}$ & $\begin{array}{l}\text { 1-economics } \\
\text { 2-politics }\end{array}$ & $\begin{array}{l}\text { 2-politics } \\
\text { 1-law }\end{array}$ & $\begin{array}{l}\text { 5-politics } \\
\text { (1 retraction) } \\
1 \text {-economics }\end{array}$ \\
\hline
\end{tabular}


Table 3. (January 1-May 31, 2015)

\begin{tabular}{|c|c|c|c|c|}
\hline No. & Distortion techniques & gazeta.ru (7) & vedomosti.ru (7) & Novaya Gazeta (19) \\
\hline 1. & $\begin{array}{l}\text { Disinformation, fabrication of facts. } \\
\text { Manifestation of selective attention } \\
\text { to facts from a favorable perspective } \\
\text { for the manipulator }\end{array}$ & $\begin{array}{l}\text { 1-economics } \\
2 \text {-politics } \\
\text { (1 retraction) }\end{array}$ & 1-economics & $\begin{array}{l}\text { 3-economics } \\
\text { (1 retraction) } \\
\text { 2-politics }\end{array}$ \\
\hline 2. & $\begin{array}{l}\text { Distortion by means of incorrect } \\
\text { citation, misrepresentation }\end{array}$ & 1-politics & & 1-economics \\
\hline 3. & $\begin{array}{l}\text { Editing, adding different meanings, } \\
\text { speculations (discrepancy with the } \\
\text { reality) }\end{array}$ & $\begin{array}{l}\text { 2-politics } \\
\text { 1-economics (retraction) }\end{array}$ & $\begin{array}{l}\text { 3-politics } \\
\text { 3-economics (1 retraction) }\end{array}$ & $\begin{array}{l}\text { 2-economics } \\
\text { 2-politics } \\
\text { (1 retraction) }\end{array}$ \\
\hline 4. & $\begin{array}{l}\text { Accompanying the material with a } \\
\text { headline inconsistent with the } \\
\text { content. }\end{array}$ & 1-economics (retraction) & & $\begin{array}{l}\text { 5-politics } \\
\text { (1 retraction) } \\
1 \text {-economics }\end{array}$ \\
\hline
\end{tabular}

Table 4. (January 1-May 31, 2015)

\begin{tabular}{|c|c|c|c|c|}
\hline No. & Distortion Techniques & Moskovsky Komsomolets (18) & Izvestia (9) & Metro (20) \\
\hline 1. & $\begin{array}{l}\text { Disinformation. Fabrication of facts. } \\
\text { Manifestation of selective attention } \\
\text { to facts from a favorable perspective } \\
\text { for the manipulator }\end{array}$ & $\begin{array}{l}\text { 3-politics } \\
\text { 2-law } \\
\text { (1 retraction) } \\
\text { 1-economics }\end{array}$ & $\begin{array}{l}\text { 2-economics } \\
\text { (2 retractions) } \\
\text { 1-politics (retraction) }\end{array}$ & $\begin{array}{l}\text { 2-politics } \\
\text { 1-economics } \\
\text { 1-law }\end{array}$ \\
\hline 2. & $\begin{array}{l}\text { Distortion by means of incorrect } \\
\text { citation, misrepresentation }\end{array}$ & 2-politics & $\begin{array}{l}\text { 2-politics } \\
\text { (2 retractions) }\end{array}$ & $\begin{array}{l}\text { 1-economics } \\
\text { 1-politics }\end{array}$ \\
\hline 3. & $\begin{array}{l}\text { Editing, adding different meanings, } \\
\text { speculations (discrepancy with the } \\
\text { reality) }\end{array}$ & $\begin{array}{l}\text { 3-politics } \\
\text { 3-economics (retraction) }\end{array}$ & $\begin{array}{l}\text { 1-politics } \\
\text { (retraction) } \\
\text { 1-law }\end{array}$ & $\begin{array}{l}\text { 6-politics } \\
\text { 3-economics } \\
\text { 1-law }\end{array}$ \\
\hline 4. & $\begin{array}{l}\text { Accompanying the material with a } \\
\text { headline inconsistent with the } \\
\text { content. }\end{array}$ & $\begin{array}{l}\text { 1-economics } \\
\text { 2-politics }\end{array}$ & 1-politics (retraction) & $\begin{array}{l}\text { 1-politics } \\
\text { 1-economics } \\
\text { 2-law }\end{array}$ \\
\hline
\end{tabular}

Table 5. (January 1-May 31, 2015)

Publication rating in terms of invoking the theme of journalism ethics

Novaya Gazeta
Moskovsky Komsomolets
Gazeta.ru
Fontanka.ru
Izvestia
Zaks.ru
News.ru
Komsomolskaya Pravda
Vedomosti.ru
Online media Lenta.ru
Arguments and Facts
Metro

As shown by the results of the study (Table 1-5), journalism deontology is discussed in two newspapers from ten, the rest almost ignore ethical norms. Low rating of the professional ethics topic indicates that the protection of moral principles, 'error analysis and correction' are not a priority of the editorial policy.

Requirements imposed on general media, accessibility and clarity, visibility lead to simplification and superficial coverage of events in the mass media texts and others.

Over the period from January to May 2015204 print media publications (online versions) concerning the spheres of politics, law and economics were analyzed. The texts were selected by continuous sampling method.
The results are given in 5 tables.

\section{Discussion}

There is a major obstacle that prevents newspapers from providing their readers with qualitative information. These are the officials who are the source of the media information, but at that consider journalists as an obstacle for the performance of their work, despite the fact that the duty of public officers to provide information to the media is enshrined in the Constitution (CRF, 1998) and the law "On Mass Media of the Russian Federation (Article 38). Moreover, public 
officers often refuse to provide journalists with the requested information (we are not talking about the information that is public, commercial or other secret one protected by law).

Some organizations and government structures offer press releases instead of credible exclusive information. In the West, the overabundance trend of useless information was seen for a long time. On this occasion, the Editor-in-chief of "Le Monde Diplomatique" Ignacio Ramonet stated: "In the twentieth century censorship acquired two seemingly mutually exclusive forms. Totalitarian regimes tried to minimize the information available to ordinary mortals. Our democratic society, on the contrary, spread the maximum of information to send the essence to the bottom of the ocean of flashy, superficial and often false news. This new more refined way of information strangulation of citizens is no less an assault on one of the fundamental freedoms, that is the ability to understand the basic problems of the world and the society in which citizens live, to that way to be able to have more opportunities to select (Ramonet, 2002).

Thus, the main problem with most newspapers published in St. Petersburg, is that they do not perform their primary function-they are not a reliable and qualitative source of information for their readers.

Low professional and ethical maturity, lack of attention to ethical violations and distorting reality prevent journalists from carrying out their direct duties.

Monitoring also helped find deep layers in the nature of general world picture distortion by the media. In recent decades, in the global spiritual continuum (also in journalism as a spiritual practical activity) the principles of post-modernism, which in many ways changed the system of values, are approved. This is due primarily to the fact that there was a change of deep essence of human consciousness, which is immersed in a semiotic space and serves as the most active subject of the creation of symbol world and symbol systems consumption.

There is a displacement of the semantics of many major semiotic codes at the level of not only everyday media practices, but also the production and consumption of media discourse, the most politicized and socialized text model. A similar trend having crucial ontological significance and correlated with many imperatives of empiricism, having very limited cognitive resources, has definitely negative humanitarian consequences. In this regard, we present a sociologist's opinion: "Despite the fact that postmodernism as an intellectual direction was developed a long time ago, at the level of mass consciousness the postmodern situation became acutely felt only now. Psychologically postmodern created crisis at the level of ordinary mass consciousness. The personal touch of this situation is the loss of criteria for right and wrong, blurring of self, a person does not know who he/she is, everything became relative, including good and evil, the value of human life, moral guidelines" (Stadnikov, 2013).

Some positive and attractive features of postmodernism were transformed a long time ago and became, in essence, their opposites. Anti-rationalism employed by postmodernism restrains the harmonious development of society and not by chance that antirationalism is interpreted in close correlating with antifunctionalism category. Principles of degenerated postmodernism, on which the creative media professionals rely, blur the documentary basis of content, thus confuse the person in the complex and sometimes hostile world, hinder from finding adequate solutions to them. Moreover, it may determine the preconditions for the emergence and spread of dangerous forms of social sphere. In a rapidly changing and complex world there is a demand for more sophisticated and effective identification tools. Today, there is a demand for postnonclassical type of rationality that provides the development of "complex, self-developing systems" (Stepin, 2009). Probably post-nonclassical rationalism has a cognitive potential that will be actualized in the future, but currently it still fails in cognitive practice and is insufficiently verifying. This fully applies to the media. It is impossible not to recognize the validity of the following statement: "Post-nonclassical science refuses to even the very possibility of constructing a unified and systemic conceptual model of the world (the principle of "post-metaphysical thinking"), actively develops the idea of chaos, substitutes the static view of the structure about the object structure by the dynamic view of the game of structure. Rejecting the idea of external causality, it converts determinism into neodeterminism. "Rediscovering the time", which is conceived as a qualitative and irreversible, is typical for post-nonclassics. Cognition becomes sensitive to the experience of transgression, i.e., overranging, overcoming the border between the possible and impossible" (Parton and Chyorny, 2006).

The media are trying to extend the territory of their influence, resorting to various tactics and strategies and expanding the boundaries of what is permitted. Journalists consciously use strategies to overcome social taboos and cultural traditions, moral regulators, consider it possible to distort both the facts of history and current events, to transform established concepts.

Often, in media texts the actions (symbolic or real), aimed at other people in order to expand control over them, are recorded and there are "any means to an end" here, including the substitution of facts, meanings change, the transformation of ideas. The purpose of the text space is to make the subject to be dismissed from his usual path of movement to the uniqueness, to abandon linearity, for which the boundaries of what is permitted 
are artificially extended. In such circumstances, the distortion of fragments of reality is inevitable.

The tendency to transgression in some texts suggests expanding the limits of applicability of linguistic resources, such as invective, slang, professional vocabulary that is used to create connotative judgments that may be adequate to reality and may not match it. Transgression in a number of texts manifests itself in nomination of absurd criteria in assessing the facts and phenomena.

Thus, one fails to leave the postmodern circle, transgression, manifested in the media, tenaciously keeps the subject of social action in it. This sentence undermines the foundations of an adequate outlook perception, it deforms cultural and mental basis for building an efficient methodological cognitive structure in discursive terms. This will possibly have serious negative consequences for the mediumistic function of the text as a complex multi code phenomenon, especially for a political text that explains many semantic shifts and distortions that can be observed in today's media discourse.

The collection of texts on various information platforms is an attempt of radical transformation of individual consciousness "and cracking the system of subordination of vital functions of the body". These contradictions require a deep interdisciplinary study not only of the emergence of distortions in the journalistic texts, but in-depth study of their impact on social practices.

\section{Conclusion}

In media environments where due respect is given to deontological values of professional culture, editorial staff should proceed from a single ethical platform or international principles of conduct for journalists. Individual codes of ethics are to comply with fundamental ethical values, served as the blueprint for the development of a single algorithm to identify transgression. Such combination of standards will encourage journalists to embrace the basic ethical principles of self-regulation and develop positive personal qualities.

Violations of journalism ethics give rise to the problem of information distortion and, as a consequence, useless, poor-quality information deforms the reality communicated to the audience. The types of poor quality information include disinformation, which is usually understood as inaccurate, incomplete or fictitious information. Systematizing the violations of ethical principles of journalism in different segments of media environment and revealing the links between them can give a clear picture of the present-day Russian mass media and open up the ways to improve self-regulatory mechanisms.

Monitoring, on the one hand, allows revealing distortions and errors in the texts of the media determined by the nature and specifics of the media- their determination at the development of intrigue, sensational, dramatic material feed, the use of infotainment technology based on the principle of "entertain informing, inform entertaining", on playing conflict model of reality. On the other hand, monitoring showed low threshold of media editorial reflection on violations of journalistic ethics, poor quality of audience information.

In the course of monitoring the North-West press the basic distortion techniques in mass media are revealed (fabrication of facts, distortion by an incomplete, onesided presentation of information, editing, adding a variety of speculation, the interpretation of facts in favorable for the manipulator light, withholding important information, any significant details, manifestation of selective attention to the facts in accordance with one's own position, supporting the material by a header not followed by the appropriate content). During the monitoring process distortions caused by getting imaginative presentation of information (figurative explanation of the processes and phenomena that do not involve understanding of their essence, actually possible links and dependencies) were also recorded.

The authors offer the typology system of meaning mistakes in media texts. The level of deformation can be defined in prospect according to this typology system and the audience reaction can be anticipated. This research allows concluding that ethics of journalism should be considered in the scientific aspect as a synonym of democracy, it is required to comply with its foundations in any country. Ethics violations that are analyzed in this article and admitted by the editorial office are not only doing harm to the democracy like some form of moral and spiritual communion, but also distort deontology of journalism-teaching the problems of morality. It is a section of professional ethics that defines interaction of rules and norms of specific media and audiences. The first requirement of journalistic ethics is thorough verification of the facts. Since journalism mistakes were not analyzed in deontological way, this type of research is thought to be important and perspective.

\section{Acknowledgment}

We are grateful to the Graduate Bachelors (32 students) of School of Journalism and Mass Communication, who monitored newspapers published in the Northwest of Russia under the supervision of faculty members in the framework of the Journalist Professional Ethics course.

\section{Author's Contributions}

Sergeevna Melnik: Designed the research plan and organized the study, literature review treatment of the empirical material. 
Boris Yakovlevich Misonzhnikov: Participated in all experiments, coordinated the data analysis and contributed to the writing of the manuscript, development of the concept, collecting empirical material.

Anastasiya Nikolayevna Grishanina: Selection of empirical material conclusion.

Alla Nikolayevna Teplyashina: Coordinated the mouse work, description of research methods, preparation of tools

\section{Ethics}

This article is original and contains unpublished material. The author confirms there are no ethical issues involved.

\section{References}

Baichik, A.V., S.B. Nikonov, A.S. Puiy and N.S. Labush, 2015. Noopolitical aspect of political defamation. Eur. J. Sci. Theol., 11: 265-275.

Bekurov, R.V., Y.V. Kurysheva, A.V. Baichik, N.S. Labush and S.B. Nikonov, 2015. Social media in sociopolitical processes. Inte. Rev. Manage. Market., 5: 137-141.

Blokhin, I. and S. Korkonosenko, 2011. Metropolis networking media: What, how and for whom. Networking media of the Russian Mediapolis. St. Petersburg.

CCJ, 2009. Committee of concerned journalists: The principles of journalism.

Chekasina, N., 2013. Sites of Modern Russian Informational Broadcasting Stations as a Media Platform. 1st Edn., NRU HSE Press, Moscow.

Christians, C., T. Glasser, D. McQuail, K. Nordenstreng and R. White, 2009. Normative theories of the media: Journalism in democratic societies. University of Illinois Press, Urbana and Chicago.

Davies, N., 2009. Flat Earth News. 1st Edn., Vintage, London, ISBN-10: 0099512688, pp: 420.

Dunas, D., 2014. Mapping Mass Communication Theories in Contemporary Russia, Word of Media. In: Yearbook of Russian Media and Journalism Studies, pp: 128-146.

Duskaeva, L.R., 2009. Ethics of Speech Behavior of the Russian Journalist. Asteron, St. Petersburg.

Korkonosenko, S., 2013. Ethics of mass communication: Experience and research in Russia and Germany. Proceedings of the International Seminar, Oct. 3-4, Spb State University Press, Petersburg.

Fedorova, A.B., 2013. Complex "picture + text": Work ethic with photo publication. Proceedings of the International Seminar, Oct. 3-4, St. Petersburg State Univ., St. Petersburg, pp: 82-84.
Franklin, B., 2013. The Future of Journalism: Developments and Debates. 1st Edn., Routledge, London, ISBN-10: 041582754X, pp: 388.

Glazkova, S., 2013. Translators false of the worldview: ethical aspects of freedom to propagate the scientific and anti-scientific views. Proceedings of the International Seminar, Oct. 3-4, St. Petersburg State Univ., St. Petersburg.

Gumpert, G. and S.J. Drucker, 2016. Regulating Social Media: Legal and Ethical Considerations. 2nd Edn., Peter Lang, New York.

Herz, M. and P. Molnar, 2012. The content and context of hate speech: Rethinking regulation and responses. Cambridge University Press.

Herz, M. and P. Molnar, 2010. The humanistic mission of the modern globalization of communication. Moscow.

IFJ, 2007. Stand Up for Journalism. http://www.ifj.org/fileadmin/images/EFJ/EFJ_docu ments/Reports/Stand_Up_for_Journalism_2007.pdf

JPTAE, 2016. http://www.de-ethica.com/

Kovach, B. and T. Rosensteil, 2001. The Elements of Journalism: What Newspeople Should Know and the Public Should Expect. 1st Edn., Three Rivers Press, London.

Maidanova, L.M. and E.V. Chepkina, 2009. Ethical and Speech Problems of Journalistic Creativity. In: Ethics of Speech Behavior of Russian Journalist: Collective Monograph, Duskaeva, L.R. (Ed.), Asteron, St. Petersburg, pp: 135-166.

Melnik, G.S., B.Y. Misonzhnikov and A.N. Teplyashina, 2015. Political discourse as the subject transgressive intention. Soc. Sci., 10: 2225-2230. DOI: $10.3923 /$ sscience.2015.2225.2230

Ovcharenko, E.F., 2011. Why Canadians do not trust the media? Bull. Moscow State Univ., 6: 24-30.

Parton, T.A. and U.U. Chyorny, 2006. People in flow of history. Nauka, Moscow.

Ramonet, I., $2002 . \quad$ To readers. http://ru.mondediplo.com/article617.html

Shishkin, D.P. and Y.V. Taranova, 2013. Issues of professionalism through the eyes of experts. Proceedings of the All-Russian Scientific-Practical Conference St. Petersburg, May 23-24, St. Petersburg, pp: 187-193.

Smirnova, E.A., 2014. Definition of the Journalistic Professional Ethics Norm. Bull. Moscow Univ. 3: 79-89.

Stadnikov, M.G., 2013. Global distribution prerequisites of modern extremism spreading. Proceedings of the Round Table Discussion, Dec. 4-4, St. Petersburg.

CRF, 1998. The Constitution of the Russian Federation. Moscow. 
Stepin, V.S., 2009. Constructive and prognostic functions of philosophy. Issues Philosophy, 1: 5-10.

Trappel, J. and W. Meier, 2011. On Media Monitoring: The Media and their Contribution to Democracy. 1st Edn., Peter Lang Publishing, New York, ISBN-10: 1433111039, pp: 306.

Trappel, J., H. Nieminen and L. Nord, 2011. The Media for Democracy Monitor: A Cross National Study of Leading News Media. 1st Edn., Nordicom, Goteborg, ISBN-10: 9186523236, pp: 366.

Tulupov, V.V., 2012. In collaboration lawyers and journalists. On the professional and ethical standards in journalism.

Voltmer, K., 2012. How Far can Media Systems Travel? Applying Hallin and Mancini's Comparative Framework outside the Western World. In: Comparing Media Systems Beyond the Western World, Hallin, D. and P. Mancini (Eds.), Cambridge University Press, Cambridge, pp: 224-245.
Ward, S.J.A. n.d. Digital media ethics. http://ethics.journalism.wisc.edu/resources/digitalmedia-ethics/

Weaver, D.H. and L. Willnat, 2012. The Global Journalist in the 21st Century. 1st Edn., Routledge, London, ISBN-10: 1136513671, pp: 530.

White, A. 2008. To tell you the truth, ethical journalism initiative.

Zarefsky, D., 2014. Arguing about Values: The Problem of Public Moral Argument. In: Rhetorical Perspectives on Argumentation: Selected essays. Springer International Publishing, London, pp: 167-177. 